\title{
"Force Majeure": The Transformation of Cultural Strategy as a Result of Urban Shrinkage and Economic Crisis. The Case of Riga, Latvia
}

\author{
Anastasiya Matyushkina*
}

\begin{tabular}{|c|c|}
\hline A R T I C L E I N F O & A B S T R A C T \\
\hline $\begin{array}{l}\text { Received: } \\
\text { July } 15,2021 \\
\text { Received in revised } \\
\text { form: } \\
\text { October } 28,2021 \\
\text { Accepted: } \\
\text { November 7, } 2021 \\
\text { Published online: } \\
\text { November 27, } 2021\end{array}$ & $\begin{array}{l}\text { Cultural strategies have been commonly used to address the } \\
\text { consequences of urban shrinkage, particularly in a post- } \\
\text { industrial context. Proliferated growth-oriented models, } \\
\text { such as "creative city," have threatened the sustainable } \\
\text { development of shrinking cities. Alternative cultural } \\
\text { models that prioritize social inclusion, local sensitivity, and } \\
\text { affordability are thus urgently needed. Using Riga as a case } \\
\text { study, this paper explores the process of transformation to } \\
\text { an alternative cultural strategy in a post-socialist shrinking } \\
\text { city and identifies planning and governance tools that } \\
\text { stimulate its development. Employing qualitative } \\
\text { interviews and document analysis, the relations between } \\
\text { emergent and deliberate cultural strategies are investigated. } \\
\text { The results show how the organization of the European } \\
\text { Capital of Culture 2014 during the severe shrinkage and } \\
\text { economic crisis led to five elements of an alternative } \\
\text { cultural strategy: (1) a shift from investing in cultural } \\
\text { "hardware" to "software," (2) a locally sensitive approach, } \\
\text { (3) cultural decentralization, (4) strengthened civic } \\
\text { engagement, and (5) inclusiveness. These elements of an } \\
\text { emergent strategy were recognized by local authorities and } \\
\text { stimulated changes in the deliberate cultural strategy. This } \\
\text { study supports the idea that urban shrinkage offers } \\
\text { municipalities an opportunity to reimagine traditional } \\
\text { planning practices and emphasizes the important role of } \\
\text { civic actors'participation in coproducing public services } \\
\text { and governance strategies. }\end{array}$ \\
\hline
\end{tabular}

Keywords: shrinking cities, post-socialist city, cultural strategy, strategy transformation, European Capital of Culture.

To cite this article: Matyushkina, A. (2021). "Force Majeure": The Transformation of Cultural Strategy as a Result of Urban Shrinkage and Economic Crisis. The Case of Riga, Latvia. Urbana, 22, 63-86. Retrieved from

http://www.urbanauapp.org

https://doi.org/10.47785/urbana.7.2021

\footnotetext{
* Department of Spatial Planning and Planning Theory, School of Spatial Planning, TU Dortmund University, Dortmund, Germany, anastasiya.matyushkina@tu-dortmund.de, +49(231)755-2246
} 


\section{Introduction}

Although urban shrinkage is not a new urban phenomenon, it occurred with renewed vigor at the end of the $20^{\text {th }}$ century. After the industrial crisis, cities all over the world experienced economic recession, followed by unemployment and residential outmigration. In Europe, the industrial recession was accompanied by natural demographic decline, political restructuring, suburbanization, and environmental pollution (Wiechmann \& Bontje, 2015). As a result of the urban shrinkage, cities faced significant financial, environmental, social, and infrastructural challenges. Research on the population trajectories of European municipalities suggests that one in five has faced significant population decline between 1990 and 2010 (Wiechmann \& Wolff, 2013). Post-socialist European countries are particularly affected by urban shrinkage. For example, in Latvia and Lithuania, more than $90 \%$ of municipalities experienced population decline between 1990 and 2010 (ibid). This trend is not expected to cease in the near future. According to the European Commission (2020), its member states will face progressive demographic decline after 2030, further threatening post-socialist states.

In the past few decades, research on shrinking cities has strongly developed. Elaborate studies exist on the effect of population decline on the economic sector (Hartt \& Warkentin, 2017; Rumpel et al., 2013), social structures (Fol, 2012; Ročak et al., 2016a, 2016b), the environment (Schetke \& Haase, 2008; Schilling \& Logan, 2008), land use, and infrastructure (Hollander \& Németh, 2011; Schenkel, 2015). However, little is written about the effect of population decline on the arts and the cultural field. This topic deserves careful exploration because traditional pro-growth models, such as "creative city" and "flagship development," have evoked heated debates regarding both their efficiency and their economic and social sustainability, particularly in shrinking cities. Critical studies indicate that such strategies often result in socio-spatial segregation, gentrification, and cultural homogenization, as well as reinforcing the "vicious circle" of urban decline (De Franz, 2013; Grodach, 2010; Lin \& Hsing, 2009; Pastak \& Kährik, 2017; Rousseau, 2009; Seo, 2002; Zukin, 1995). It has become clear that an innovative approach to cultural strategy is needed.

The purpose of this paper is therefore to investigate an alternative approach to cultural strategy in shrinking cities. To this end, it is helpful to understand whether there is a real need for an alternative cultural strategy in the context of shrinking cities and, if there is, how the transformation towards an alternative approach occurs. We hence address the following research questions: (1) How does urban shrinkage affect the cultural field, and why is an alternative approach needed? (2) What are the alternative elements in a cultural strategy? (3) How is the alternative cultural strategy developed, and which planning and governance tools stimulate its implementation?

The analysis of a novel approach to cultural strategy necessitates a critical exploration of cultural governance and the role of culture in urban development, expanding its role from an economic and marketing tool into a tool for social cohesion and civic empowerment. In this paper, the term culture is understood as a process of human intellectual and aesthetic development, which is manifested in cultural products such as architecture, traditions, or the arts (Lyman, 2007; Williams, 1985). Moreover, cultural strategy is defined as a course of action, where cultural process and products are utilized to achieve an intended set of goals (author's definition based on Mintzberg et al., 1998).

On the empirical level, this paper presents the case of Riga - one of the most rapidly shrinking capitals in Europe. The analysis follows Riga's process for developing an innovative cultural strategy to win the title of the European Capital of Culture (ECoC) under the rigid conditions of a world economic crisis and severe urban shrinkage. According to Beauregard (2009), severity measures the scale of population decline. Since Riga lost over a third of its population between 1989 and 2021, we adopt the term "severe urban shrinkage" to highlight this large scale. 
Our paper is structured as follows: First, we discuss the specifics of shrinking cities and propose theory-driven assumptions about how they affect the arts and cultural field. This analysis is followed by several suggestions on how cultural strategies in shrinking cities should be adopted. Thereafter, we describe the methodology and present the context of Riga. In the results, we investigate how the transformation toward an alternative cultural strategy occurred in Riga and what planning and governance instruments facilitated it. Finally, in the conclusion and discussion, we summarize the key findings and link them to the broader debate on urban development in shrinking cities.

\section{How Urban Shrinkage Affects the Cultural Field}

To investigate the directions for the sustainable transformation of a cultural strategy in shrinking cities, it is essential to understand how urban shrinkage affects the cultural field and why an alternative to a pro-growth strategy is needed. There is currently a lack of studies offering empirical evidence on the effect of urban shrinkage on the cultural sector. This is often associated with a lack of sufficient statistical data on the number, quality, and accessibility of cultural services and the level of cultural consumption. In Latvia, for example, the Central Statistical Bureau provides longitudinal data on the number of cultural institutions at the national level, for museums, theaters, cinemas, libraries, and cultural centers. However, this information is not available at the Riga city level. Despite the lack of data and empirical evidence, we consider it valuable to launch a discussion about the possible implications of urban shrinkage on the cultural field. Therefore, the first research question is explored through a literature review: we discuss the specific characteristics of shrinking cities and propose four theory-driven heuristic assumptions about how the arts and cultural field is affected.

First, studies show that outmigration in shrinking cities is a selective process (Fol, 2012; Hospers, 2013; Miot, 2015; Slach et al., 2019). Young, qualified, and educated people usually tend to move out first. In contrast, the elderly and socially underprivileged groups find it challenging to change their place of residency; thus, they become dominant groups in the social structure (Hospers, 2013). In post-industrial contexts, some studies report high unemployment and impoverishment of their residents (Blanco et al., 2009; Rink et al., 2010). In places where most cultural services require a fee, impoverished and unemployed residents do not have many opportunities to access cultural services.

Culture is one of the social markers of a certain lifestyle, identity, and status. In one of Bourdieu's influential works (1984), he suggests that "people internalize their class position and express it in cultural choices" that reproduce the class structure (Katz-Gerro, 2002, p. 208). Another classic theory on cultural consumption proposed by Peterson (1992) states that higher and lower social classes differ not in terms of their cultural tastes but in terms of the intensity and variety of their cultural consumption. Therefore, the division is not between highbrow and lowbrow cultural consumers but between cultural omnivores and cultural univores. The mentioned theories of cultural consumption suggest that there is a difference in demand for cultural services within different groups of residents. There is thus evidence that the social structure in shrinking cities leads to a decline in the variety of cultural consumption. Instead, an increase in demand for univore and lowbrow cultural services can be present (for example, for hobby art activities or pop culture events).

Second, several studies confirm that shrinking municipalities struggle with declining tax revenue, which leads to fiscal cutbacks and a rollout of services (Audirac, 2018; Berglund, 2020; Bierbaum, 2020; Hackworth, 2015). Under conditions of tight financial resources, municipalities are forced to make efficient investments in the most essential services and amenities. In this context, cultural policies are often considered as "nice to have" and do not receive the same political priority as, for instance, education or healthcare. This is why during times of financial austerity, cultural budgets are often cut first (Henley, 2016). Therefore, as a 
second assumption, we conclude that cultural budget cuts in shrinking cities lead to a declining number and quality of cultural services.

Third, several studies suggest that infrastructure services are unequally distributed in shrinking cities (Audirac, 2018; Bierbaum, 2020; Slach et al., 2019). From an economic perspective, it is rational for shrinking municipalities to develop and invest in areas with higher density (Slach et al., 2019). They consequently often follow a centralized approach to infrastructure planning. Many studies confirm that culture-led regeneration projects are often located in areas with the highest return on investments, such as in city centers or waterfronts (Boland, 2007; Darchen \& Tremblay, 2013; Pastak \& Kährik, 2017; Sobala-Gwosdz \& Gwosdz, 2018). Therefore, our third assumption is that cultural infrastructure and services in shrinking cities are unevenly distributed when following a centralized approach. However, some studies argue that decentralized and small-scale cultural infrastructure, such as community halls and art centers, not only have an important function in encouraging local vitality and creativity but also might provide an efficient strategy for cultural development (Gibson et al., 2012, p. 299).

The fourth commonality of planning practices in shrinking cities concerns their overemphasis on quantitative and physical improvements and a lack of attention to qualitative and social aspects. Analyzing the European shrinking cities, Cortese at al. (2014) point out that social cohesion policies remain in the shadow of physical and economic policies to address urban shrinkage. Audirac (2018) confirms these findings in the North American context, pointing to the overfocus of urban strategies and academic research on "hardware" planning, with little attention to social equity and justice. Both authors conclude that more attention should be paid to the social dimensions of declining cities.

Audirac also states that social inequality may result in the spatial stigmatization of shrinking areas. The stigma - defined as "symbolic degradation" - negatively affects residents' sense of self and their capacity for collective action (in line with Martinez-Fernandez et al., 2016 , p. 5). As a response, culture can play a central role in addressing the problems of negative urban image and stigmatization (Ročak et al., 2016b, p. 11). However, with the neoliberal turn, cultural values and artistic practices have been increasingly instrumentalized for economic and property-led goals (Binns, 2005; Lysgård, 2012; Sayer, 2001), especially in post-socialist cities that are characterized by weak state intervention and an extensive involvement of the private sector in urban development (Galuszka, 2017; Nedučin et al., 2019). The economized approach to culture significantly limits its broader sociocultural functions. Moulaert et al. (2004) discuss the expanded role of culture in urban development as (1) a mode of communication, (2) an enabler of social identity and shared collective vision, (3) a tool for raising awareness and expressing public dissatisfaction, and (4) a medium for civic participation. These functions of culture contribute to developing the "social software" of cultural initiatives (Sacco \& Blessi, 2009).

Breaking with the materialistic view on culture and acknowledging the importance of sociocultural functions for improving people's quality of life has become one of the approaches with which shrinking cities experiment. Such cases have been successfully implemented in East Asia, Europe, and North America (see Gribat, 2017; Joo \& Hoon Park, 2017; Koizumi, 2015; Winkler et al., 2016). Joo and Hoon Park (2017) documented one such model of cultureled regeneration in Busan, Korea. The project - the redevelopment of the old industrial downtown - focused on promoting the intangible cultural values of the district and reviving the community spirit. The non-state project leaders aimed to minimize physical change and preserve the urban history shared by local residents, with the idea that urban regeneration would follow. The authors report that the project improved residents' quality of life, developed social capital, and even triggered a socially driven transition in the municipal cultural policy. This project illustrates how urban regeneration can be achieved through the development of 
substantive software "without big investments and physical renovation, toward enhancing intangible values of locality" (Joo \& Hoon Park, 2017, p. 859).

Sacco and Blessi (2009) also argue that investments in "software" is crucial: "without proper, supporting 'social software', massive investment in new cultural facilities may assume a dysfunctional 'cosmetic' character that is likely to exacerbate the critical aspects of urban transformation rather than tempering them" (p. 1115). This leads to the final assumption that cultural strategies in shrinking cities follow a physical and economic "hardware" approach. However, due to the increasing social and mental problems in shrinking areas and the ability of culture to address them, cultural strategies in shrinking cities should prioritize "social software" to tackle the consequences of urban shrinkage.

In summary, the state-of-the-art research on culture and shrinking cities reveals several points about how urban shrinkage affects the cultural field, which allows us to derive why an alternative to a pro-growth approach is needed:

(1) The changes in demographic structure might lead to a decline in cultural consumption, particularly in the highbrow and professional arts. Therefore, changes in cultural offers are required, for instance an increase in popular and amateur cultural activities and improvements in physical and financial accessibility of cultural services to elderly and socially underprivileged groups.

(2) The financial austerity of shrinking municipalities might lead to cultural budget cuts, declining availability and quality of cultural services, and a decline in support for cultural amenities and employment. Cultural strategies might include flexible financial schemes to ensure sufficient support for cultural institutions, as well as to innovate with affordable strategies for cultural development.

(3) Shrinking cities might experience an unequal (often centralized) distribution of cultural infrastructure services, which reinforces socio-spatial segregation. Therefore, improving accessibility to and the spatial decentralization of cultural services should be prioritized.

(4) Shrinking cities are characterized by an overemphasis on hardware planning and a lack of attention to social problems. Culture as a planning tool can be efficient in tackling social problems; thus, cultural strategies should prioritize investments in "social software."

In the next sections, we describe the research design and methods for the empirical part of this study to answer the two remaining research questions: (2) What does an alternative cultural strategy imply? (3) How is the alternative cultural strategy developed in Riga, and which planning and governance tools stimulate its implementation?

\section{Research Design and Methods}

The empirical part of this research is based on a single-case-study methodology. Gerring (2007) defines a case as a "spatially and temporally delimited phenomenon of theoretical significance" (p. 27). The advantage of single-case studies is that they allow researchers to explore one complex social phenomenon in depth, account many details, and find explanations that standardized quantitative methods are not able to find. Moreover, a single-case study allows one to gain a more precise understanding of the circumstances in which the social phenomenon develops; in that sense, it can be even more reliable and insightful than multiple-case studies (Stake, 2000). This study does not claim to produce generalizable empirical evidence about the development of one-size-fits-all sustainable cultural strategy for shrinking cities. Instead, the goal of using a single-case-study methodology is to conduct a longitudinal in-depth analysis of cultural strategy development in a context of a post-socialist shrinking city, as well as identifying the strategy elements and planning tools occurred in that particular context. Among the population of post-socialist shrinking cities, we selected Riga in Latvia. The case was analyzed within the temporal boundaries of 2004-2021 - the period of severe shrinkage and 
global financial crisis until the time of writing. The choice of a longitudinal case aims to track how the trajectory of urban shrinkage developed and affected the transformation of a cultural strategy.

The object of analysis in this study is the cultural strategy in Riga. In strategic planning, two forms of strategy are distinguished: deliberate and emergent (Mintzberg et al., 1998). A deliberate strategy entails an intended, explicitly formulated (in official documents) course of action that is implemented by engaged stakeholders. However, an efficient strategy often cannot result from a predetermined top-down plan. Therefore, another type of strategy is crucial: an emergent strategy, which comprises a course of action that was not initially expressly intended but, after its incremental realization, "converged to some sort of consistency or pattern" (Mintzberg et al., 1998, p. 11). A real-world strategy can rarely be purely deliberate or emergent; it is usually a mix of both predictive top-down planning and reactive bottom-up actions (see Figure 1). Such a combination contributes to effective management because the deliberate strategy "enriches an organization with a sense of purposeful direction," whereas an emergent strategy "implies that the organization is learning incrementally" (Wiechmann, 2007, p. 5). According to Mintzberg (1998), effective strategies should contain emergent qualities because these qualities drive strategic learning, novelty, and organizational capacity to experiment.

\section{Figure 1}

Forms of Strategy

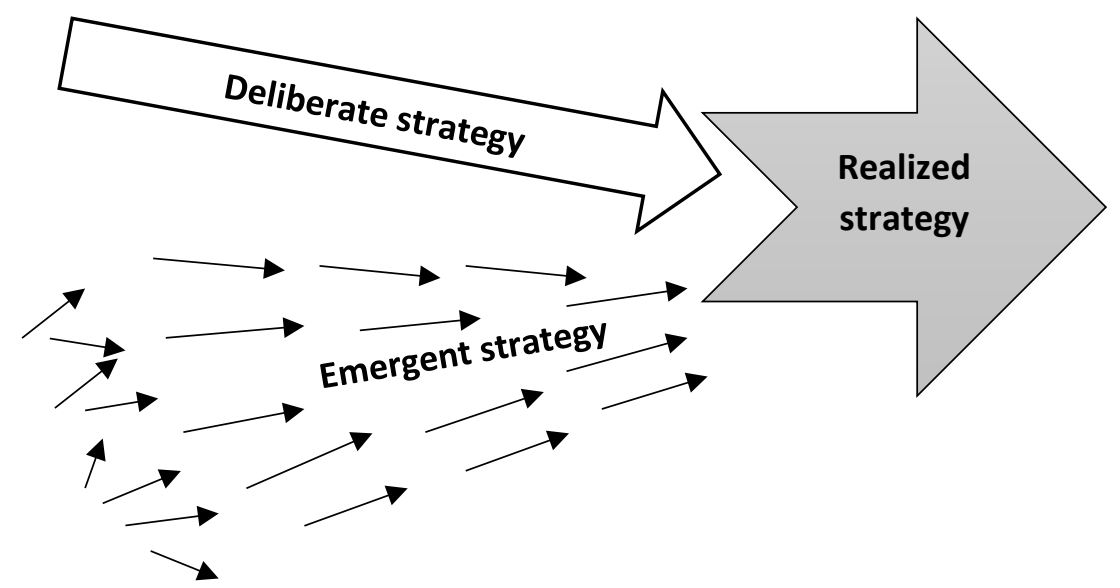

Source. Mintzberg et al., 1998, p. 12.

In shrinking cities, the demand for experimentation with alternative solutions is high, but public authorities generally struggle to innovate them on their own. Budget deficits, a rising number of infrastructural and social problems, and the lack of institutional capacity often prevent public authorities from taking risks, experimenting, and innovating (Hospers, 2014; Schlappa, 2017). Many authors thus emphasize that in shrinking cities, "local authorities will not be able to cope with the effects of shrinkage of their city on their own" (Stryjakiewicz \& Jaroszewska, 2016, p. 34) and must stimulate bottom-up solutions that engage civic actors (Haase et al., 2012; Hospers, 2013; Ročak et al., 2016a; Schlappa, 2017).

In our strategy analysis, we distinguished between emergent and deliberate strategies in order to see how each type transforms under the conditions of economic crisis and severe urban shrinkage, how they affect each other, and whether both of them can provide an efficient alternative approach to cultural strategy. Therefore, our analysis of strategy transformation 
consisted of two phases. In the first phase, the emergent or the "actually existing" cultural strategy in Riga was investigated. For this, semi-structured interviews were used as the primary source of data. We conducted 21 semi-structured interviews with the stakeholders involved in urban and cultural planning and bottom-up cultural activities in Riga (see Appendix). The majority of the interviews were conducted in person in October 2019 and September 2020. However, during the COVID-19 pandemic, a few interviews took place online via video calls. All interviews were held in English or Russian and transcribed by the author. The research participants were identified via snowball sampling and represent different types of professions: civil servants, cultural NGO professionals, activists, artists, and residents, as well as a landscape designer and a private property owner. The variety of stakeholders ensured the reliability of data and allowed for all-encompassing insights about the incremental actions that have become part of the emergent strategy during the selected timeframe.

In the second phase, the deliberate cultural strategy was analyzed based on three types of official strategic documents: a long-term municipal development strategy, a short-term municipal development strategy, and a municipal cultural strategy. The long-term development strategy of Riga established the vision for city development, strategic objectives, spatial development perspective, and priorities. The mid-term development strategy established the action plan and the division of tasks to be implemented. Finally, Riga's cultural strategy established a long-term development vision, strategic goals, and development priorities in the cultural field, considering the national and regional cultural policy directions. Overall, seven strategic documents were analyzed (see Table 1). These texts were in Latvian and translated via Google Translate. Where available, an English version was examined to ensure the accuracy of translation and the coherence of the used terms and definitions. The primary and secondary data were analyzed in MAXQDA using content analysis - a method associated with the study of inscription contained in documents, texts, or speeches (Prior, 2014).

Table 1

Strategic Documents Included in the Analysis.

\begin{tabular}{|c|c|c|}
\hline № & Document title & № of pages \\
\hline \multicolumn{3}{|c|}{ Long-term strategic documents } \\
\hline 1 & Riga long-term development strategy until 2025 & 63 \\
\hline 2 & Sustainable Development Strategy of Riga until 2030 & 83 \\
\hline \multicolumn{3}{|c|}{ Mid-term strategic documents } \\
\hline 3 & Riga Development Program 2006-2012 & 197 \\
\hline 4 & Riga Development Program 2010-2013 & 86 \\
\hline 5 & Riga Development Program 2014-2020 & 116 \\
\hline \multicolumn{3}{|c|}{ Cultural strategic documents } \\
\hline 6 & Riga City Cultural Strategy for 2008-2025 & 26 \\
\hline 7 & Riga City Municipal Cultural Strategy for 2017-2030 & 25 \\
\hline \multicolumn{2}{|r|}{ Total: } & 596 \\
\hline
\end{tabular}

\section{Context of the Case Study - Riga, Latvia}

\subsection{Urban Shrinkage}

According to Wiechmann and Wolff's (2013) typology of European shrinking cities, Latvia tops the list of countries with the largest share of continuously shrinking cities between 1990 and 2010 (See Figure 2). 


\section{Figure 2}

European Cities with Population Loss, Stability, and Growth from 1990-2010 per Country.

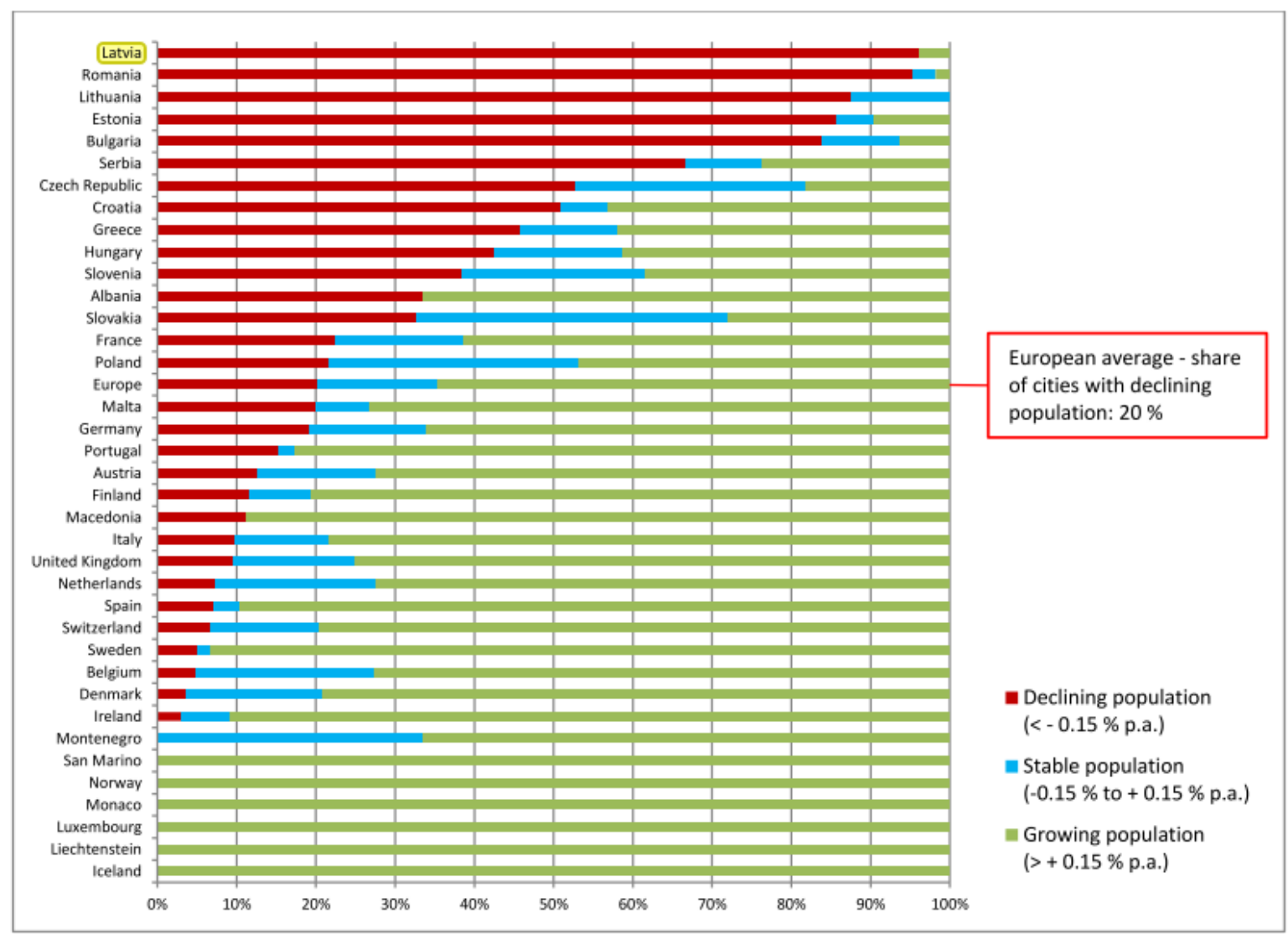

Source. Wiechmann \& Wolff (2013, p.11).

Riga is the capital of Latvia. More than $30 \%$ of the Latvian population resides in Riga. Even with a population decline of over $30 \%$ in the last 30 years, Riga remains the largest city in the Baltics. The process of urban shrinkage in the city resulted from negative natural population change, outmigration, and suburbanization. The outmigration process in Riga occurred over four waves (see Figure 3), triggered by political and economic factors: (1) the fall of the Soviet Union, (2) high unemployment before Latvia's EU accession; (3) Latvia's accession into the EU, and (4) the world economic crisis of 2008-2009. The processes that occurred during each of the outmigration waves are summarized below.

(1) During the Soviet occupation of Latvia from 1944 to 1989, Riga underwent rapid industrialization and collectivization processes. The city grew substantially - the population almost doubled, and infrastructure increased rapidly. The population growth was largely driven by the influx of the Russian-speaking population who entered the city either forcefully (to join the industrial and military sector) or voluntarily, as the Baltic States had the highest wages and living standards in the Soviet Union (Hazans, 2013). Demographic growth was the main result of the rapid development of industries and the military sector. Fast urbanization processes led to overstretched urban infrastructure: mass housing estates, transportation, and gray and social infrastructure. After the fall of the Soviet Union, the armed forces withdrew, and the industrial sector declined. Outmigration mostly occurred within the Russian-speaking population - those employed by the Soviet administration and the industrial sector, and army members. 


\section{Figure 3}

Population Decline and the Four Stages of Outmigration in Riga, Latvia, 1987-2019.

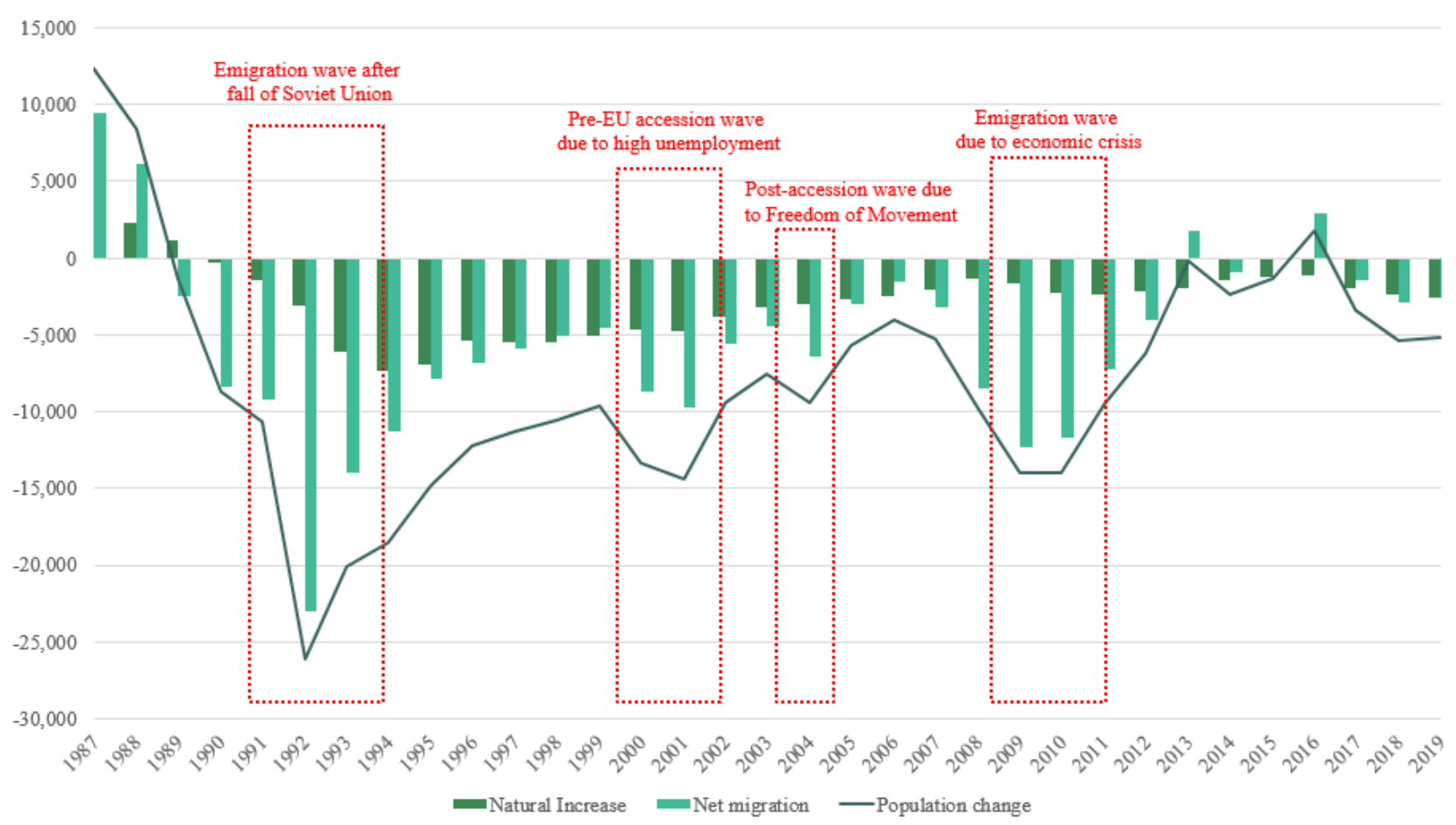

Note. Author's Compilation Based on Data from the Central Statistical Bureau of Latvia.

(2) The second wave is associated with the pre-EU accession of Latvia to the European Union. Just before the accession, the country faced high levels of unemployment and low salaries. Many highly educated residents of working age migrated to improve their material wellbeing. It is important to note, however, that several independent studies contradict the data provided by the Central Statistical Bureau of Latvia, claiming that the pre-accession wave was considerably smaller than the post-accession wave (Hazans, 2019; Krasnopjorovs, 2011).

(3) The third large wave occurred after the EU accession of Latvia in 2004. The freedom of labor movement significantly reduced costs and mental barriers of migration. After Latvia became an EU member state, its economy and labor market began to grow, retaining some of the residents inside the country and attracting a return of immigrants (Hazans, 2019).

(4) The fourth large wave of outmigration occurred during the world economic crisis of 20072008. Compared to the majority of European countries, Latvia was severely affected by the crisis, with full-time employment dropping by over 30\% by 2010 (Hazans, 2013, p. 66). Working-age residents migrated to E.U. countries with low unemployment such as Norway, the Netherlands, and the UK. The emigration during 2009-2011 reached unprecedented speed to the extent that it "pose[d] a threat to the reproduction of the Latvian population, the country's economic development and the sustainability of its social security system" (Hazans, 2019, p. 67).

The research by Hazans (2019) also indicates that $57 \%$ of emigrants from Latvia in the 21 st century were female, which aggravated the declining birth rates in the country. Moreover, the country lost a large number of younger (under 35) and educated people. This fact further intensified an aging population, as well as an economic and labor decline. Despite the steady 
population decline, the gross domestic product of Latvia and Riga steadily grew, and the unemployment rate declined. However, a large proportion of the employees in Riga were residents of other municipalities, so-called work commuters (people who work in Riga but live outside its territory). The process of suburbanization resulted in the city losing a large part of the total amount of potentially obtainable personal income tax (Riga City Council [Rīgas dome], 2005b, p. 6).

\subsection{Cultural Landscape}

Being the capital city of Latvia and one of the largest cities in the Baltic Sea Region, Riga has a rich cultural landscape that is recognized internationally. The city center is one of the UNESCO World Cultural and Natural Heritage sites. Riga is known for having the world's highest quantity and quality of Art Nouveau architecture and unique wooden architecture. As the capital city, Riga is home to important state, municipal, and private cultural institutions (Riga City Council [Rìgas dome], 2014a).

However, despite the sufficient number of cultural institutions and historical buildings, many of them are concentrated in the city center and are unequally distributed across residential neighborhoods. The limited number of cultural institutions in the periphery creates unequal access of residents to cultural participation, which threatens social justice and raises further questions about the equitable access to public resources in shrinking cities (in line with Bierbaum, 2020). In addition, many cultural and historical buildings are in poor or emergency conditions, which might lead to further closures of cultural institutions. The municipality lacks effective measures for cultural preservation and restoration (Riga City Council [Rīgas dome], 2014a, p. 87). Moreover, the city still lacks some crucial cultural infrastructure, such as a contemporary art museum and large exhibition spaces.

\section{Results}

In this section, the deliberate and emergent cultural strategies in Riga are analyzed: we track the transformation of cultural strategy in the official strategic documents of Riga city and explore cultural actions taking place on the ground. The data revealed that the $2014 \mathrm{ECoC}$ has been the central event that unveiled the innovative emergent strategy and triggered changes in the strategic approach toward culture in policy and planning. Therefore, the ECoC 2014 is the central theme in the analysis. We approach this section in chronological order. First, we analyze the approach to culture in the deliberate strategy before the ECoC 2014 event. Then, we analyze the process of the ECoC organization and implementation as the emergent strategy, and we describe its consequences for the deliberate strategy. We identity five main elements that indicate Riga's cultural strategy transformation toward being more efficient and sustainable: (1) the shift from investing in cultural "hardware" to "software," (2) a locally sensitive approach, (3) cultural decentralization, (4) strengthened civic engagement, and (5) inclusiveness. We also investigate the tools and instruments that encouraged these strategy transformations.

\subsection{The Transformation of the Deliberate Cultural Strategy}

Riga was selected to be the ECoC 2014. The European Union awards this title to one or several cities for one year, during which they organize cultural events. Every year, many cities compete for this opportunity because the title not only allows them to generate positive outcomes for their city and region but also raises their visibility and international profile. Winning this title is a long process that takes several years of developing the application, developing the event program, and then implementing it. 
Having a long-term strategy for cultural development is one of the crucial eligibility conditions for ECoC candidacy. Therefore, in 2008, alongside the development of the application, Riga approved its first municipal cultural strategy for 2008-2025 (INT_09). To a large extent, the strategy considered culture to be the engine for economic and employment growth. It emphasized the role of creative economy and cultural industries, as well as international tourism. Prioritizing these growth-oriented industries aimed to strengthen the city's competitiveness and promote an internationally oriented image of Riga. The restoration of cultural heritage was prioritized both for its ability to increase property values and as an added value for tourism and other economic sectors (Riga City Council [Rīgas dome], 2008, p. 5). Overall, the document presented a cultural strategy typical for a post-industrial city trying to reverse the demographic and economic decline back to growth (Bianchini \& Parkinson, 1993). On the one hand, it treated culture as an economic and marketing tool and catered largely to the interests of investors and tourists. On the other hand, the strategy already recognized the problem of uneven distribution of cultural services in the city and the lack of their accessibility for diverse groups of the population, especially children, youth, socially excluded groups, and residents with special needs. Furthermore, the strategy mentioned public participation as one of the principles of cultural strategy, although it offered little elaboration on how this participation could be elicited (Riga City Council [Rīgas dome], 2008).

After the ECoC, the second municipal cultural strategy for 2017-2030 was approved. The innovations and lessons learned during the realization of the emergent cultural strategy were applied in the new deliberate strategy. There, culture was no longer seen as a tool for economic gains but was interlinked with social integration, civic participation, and neighborhood development. Instead of promoting the international image of Riga, the new deliberate strategy built on the concept of a neighborhood and prioritized the development of cultural services in residential areas (Riga City Council [Rīgas dome], 2017). Instead of creative and cultural industries, it emphasized the amateur arts and popular cultural offers intended to increase cultural inclusiveness for diverse population groups. Section 5.2 elaborates on how these strategy transformations occurred.

\subsection{The Transformation of the Emergent Cultural Strategy}

\subsubsection{From Cultural "Hardware" to Cultural "Software"}

In Riga, the concept and program for the ECoC was developed by an independent foundation formed specifically for the event and headed by the director of the Cultural Department of the Riga City Council. Preparations for the ECoC began in 2008, the year in which the world economic crisis hit. One of the representatives of the ECoC Foundation explained, "We had the program titled Force Majeure, because we started this project when it was an absolute crisis all over the world." The economic situation in Riga was difficult, especially in preparation for an iconic event. Cities that become cultural capitals tend to invest in constructing cultural infrastructure and running urban regeneration projects. The Latvian national and Riga city governments also planned several ambitious infrastructure projects for the year of the ECoC, including "the new building for the Latvian National Library, a new Riga Concert Hall, an improvement programme for the National Museum of Art and a new Contemporary Art Museum in a former thermal power plant" (European Commission, 2015, p. 46). Of these, only the first two projects were completed as part of the ECoC program; the rest did not succeed due to the bankruptcy of their investors (ibid.).

Latvia was one of the European countries most severely affected by the economic crisis. According to the official information in the Municipal Public Reports, during 2009-2010, the budget of the Ministry of Culture was cut by $42 \%$ (see Figure 4), and the municipal cultural budget in Riga by almost half (49\%). The lack of private investments and significant public 
cuts negatively affected a large number of actors in the arts and cultural sector and limited the scope of cultural offers in the city (INT_4). When it became clear that the infrastructure projects could not be realized, the ECoC Foundation decided to invest in cultural software - in support of cultural institutions and civic initiatives to help them service and sustain cultural services: "we did not invest in buildings; we invested in communities" (INT_14).

The strategy to focus on cultural software is in line with Oswalt's (2005a, 2005b) idea of "weak planning" or Elzerman and Bontje's (2015) notion of "alternative planning." The authors argue that "soft" planning tools, such as cultural development or the empowerment of social networks, present a prime opportunity to move from the traditional "hard" physical types of planning and trigger an attitude change regarding urban shrinkage as an opportunity rather than a threat. In Riga, the development of cultural software was realized through the geographical division of the city into smaller spatial areas: neighborhoods. Next, we describe how these processes go hand in hand.

\section{Figure 4}

Budget Expenditure of the Ministry of Culture (in Euro).

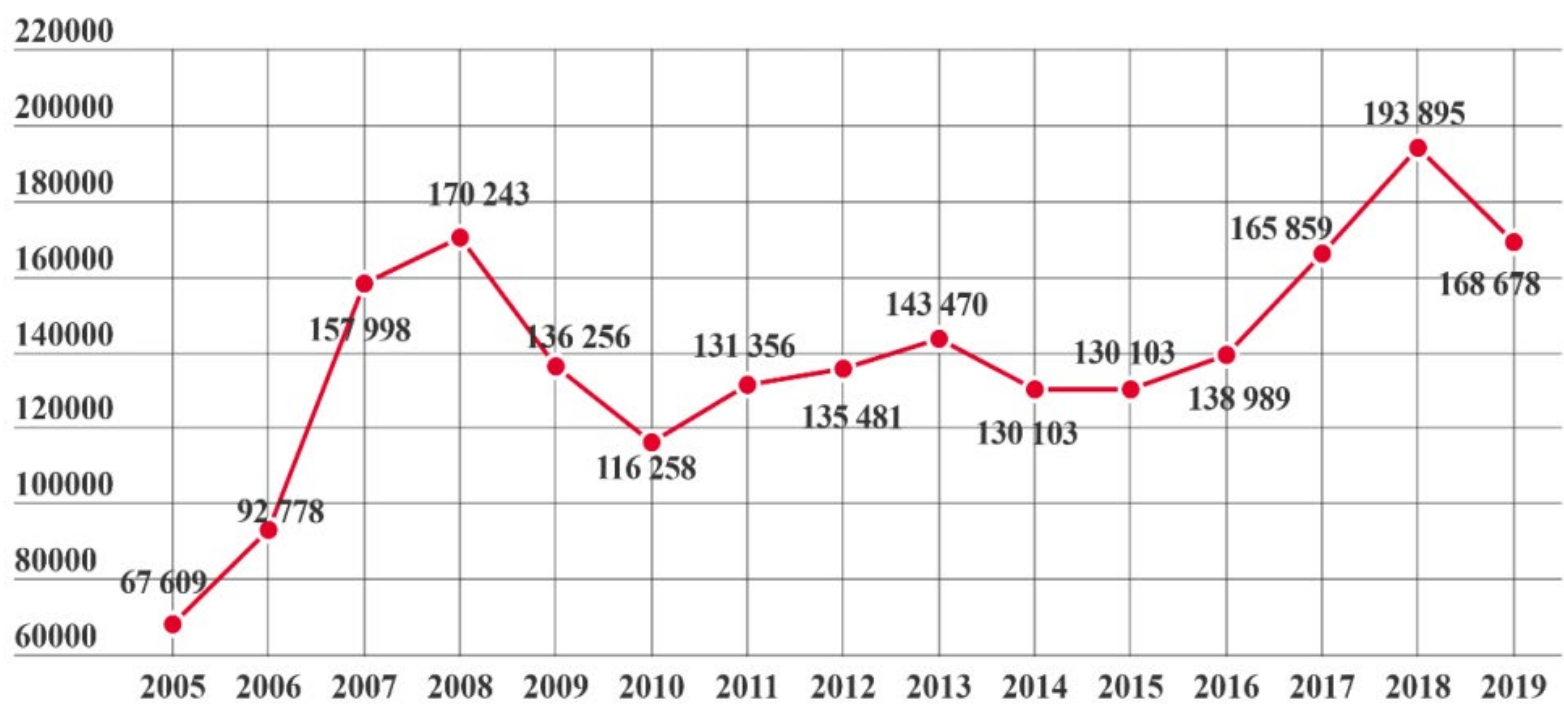

Source. Ministry of Culture of the Republic of Latvia, 2020, p. 13.

\subsubsection{Toward a Locally Sensitive Approach}

In 2007, the City Development Department of the Riga City Council started working on a new spatial concept that divided Riga into 58 neighborhoods. The initial idea was for the neighborhoods to serve as statistical borders for analytical purposes to monitor urban processes such as the medium temperature in hospitals (INT_08). However, after the consultation phases in 2011, the idea took on a different meaning: "underscoring the integration of local society the communities - in the city" (Gugane, 2020). Now, the urban development strategy defines a neighborhood as a suitably sized population with its own identity and character, which stems from the type of building, physical boundaries, landscape, and a sense of community (Riga City Council [Rīgas dome], 2014b). Interestingly, in many cases, the neighborhoods were not artificially created, but reproduced the historical boundaries of manors, hamlets, or villages, which merged into the modern city of Riga (INT_08). Thus, for some areas, the historical identity of place existed, yet it needed to be rediscovered. 
Culture served as the main driver to rediscover the identity of the new geographical territories, around which people could gather, connect to their part of the city, and form a community. The ECoC Foundation picked up the neighborhood division concept and decided to use it as a map to one of the six events of the cultural program (INT_14). This event - titled the Road Map - invited residents to think about city development issues in their neighborhoods and offered small funds to implement their ideas. In addition, several experts were invited to help residents develop their ideas into feasible projects (INT_02). As a result, 117 projects took place in Riga neighborhoods: guided tours, bicycle routes, open house days, theater and circus performances, and social gatherings in unusual places (European Commission, 2015).

The Road Map relied on residents' knowledge of local resources such as public spaces or local history, and it allowed people to find solutions to acute problems in their neighborhoods. This gave rise to the locally sensitive approach to planning, where culture appeared as a local resource and a tool for civic participation. The project also relied on local human resources - residents who volunteered to design and implement their own projects. Given the limited financial resources, volunteering enabled successful event realization and strengthened the capacities of neighborhood-based actors. According to the ECoC ex post evaluation, $87 \%$ of civic organizations felt that their capacity in the longer term had "strengthened" or "significantly strengthened" (European Commission, 2015, p. 66). These actions affected the deliberate strategy: the municipal cultural strategy for 2017-2030 recognized the coordinated involvement of volunteers in organization of ECoC 2014 as one the most successful forms of participation (Riga City Council [Rìgas dome], 2017, p. 14).

\subsubsection{Cultural Decentralization}

The distribution of cultural infrastructure in Riga follows a centralized approach: the majority of such infrastructure is located in the city center, while $65 \%$ of residential neighborhoods have no cultural amenities and services in their vicinity (Riga City Council, 2021). Within the Road Map project, the communities organized a wide range of cultural events in their neighborhoods, which ensured wider participation of diverse social groups, including the marginalized and socially underprivileged (INT_14). One of the neighborhood activists shared:

Something was happening in the neighborhood, finally. Because a lot of things always happen only in the center, for tourists. And you need to come to downtown to experience some things like contemporary arts or any other genres, so we try to bring something in a neighborhood (INT_02).

According to the European Commission's ex post evaluation of the ECoC, "this ensured that culture was found next door and in the faces of marginalized communities in a way that had not occurred before" (European Commission, 2015, p. 52).

These emergent actions affected the deliberate strategy. The municipal cultural strategy for 2017-2030 states that communities are more active in neighborhoods with a sufficient number of cultural amenities. For example, it was found that neighborhoods of the Soviet epoch lack community meeting spaces, and their residents are less active in cultural participation, while old historical neighborhoods of Riga that have community spaces and cultural centers have higher levels of civic participation. The most efficient type of cultural infrastructure for residential neighborhoods is a multifunctional neighborhood cultural center. The renovation and construction of multifunctional cultural centers outside of the center hence became a strategy objective for 2017-2030 (Riga City Council [Rìgas dome], 2017, p. 14). 


\subsubsection{Strengthening Civic Engagement}

The neighborhood division concept and the engagement of neighborhood communities in the ECoC program served as fertile ground not only for cultural decentralization but also for civic engagement. The Road Map encouraged neighborhood residents to participate in the urban planning process and provided them with capacities and resources to realize their ideas. According to the report of the European Commission (2015), 47\% of activities were organized by local communities.

These neighborhood initiatives around cultural events gave rise to neighborhood-based associations (NAs) - nongovernmental organizations formed by local inhabitants. One of the NA representatives shared:

I believe that the fact that the Riga City Council created neighborhood divisions really helped some of the neighborhoods to develop, to organize themselves, including myself. I started to found an NGO only after the neighbourhood concept presentation, for example.

In their interview, a representative of Riga City Council noticed that before the implementation of the new spatial concept, only three NAs existed in Riga. However, after they started to promote the idea of identity, a sense of belonging, and community building, more than 20 NGOs emerged in Riga neighborhoods (INT_08). In Figure 5, neighborhoods with NAs are depicted in green, and neighborhoods with an NA that is also part of the umbrella organization - the "Riga Neighborhood Alliance" - are shaded in a striped green.

NAs play an important role in developing cultural and leisure offers in the neighborhoods. Many NAs are involved in organizing cultural activities with residents, some of which aim at improving the urban environment. In their interviews, the representatives of three NAs described culture as a positive instrument to attract attention to urban problems, mobilize people, and raise public awareness (INT_02, INT_19, \& INT_21). However, one of them also said that cultural projects were only useful at the beginning of their work but are no longer efficient for their goals. Now, instead of cultural projects, they focus on larger and hazardous issues such as river pollution:

I stopped doing small things with culture. We did it for the first 4 years in order to raise awareness between local inhabitants. We made the neighborhood a bit more visible and more appreciated by the locals, by creating some cultural events. It was not about art per se, it was about public space. Culture is an instrument to raise awareness, rather than really do culture, in my case (INT_02).

In another neighborhood, the residents organized a theater play at a degraded cemetery. The NA representative described culture as a positive instrument to attract attention to problematic zones: "the cemetery was being degraded, and we thought we could address it through something positive - rather than riots. So we give it a focus through arts." (INT_21). 


\section{Figure 5}

Map of Neighborhoods with Neighborhood Associations, on March 2021.

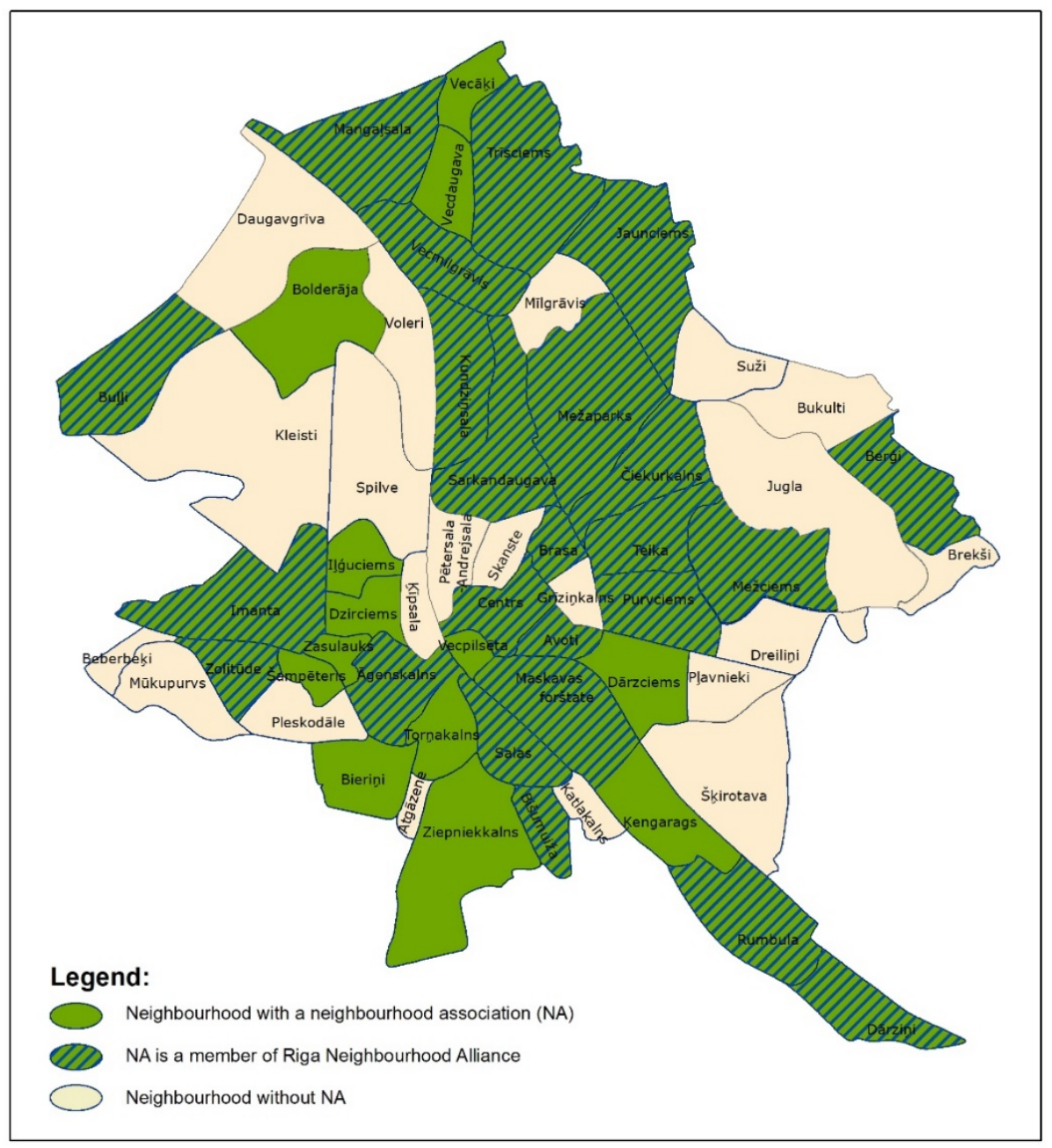

Note. Provided by the Riga City Development Department.

The neighborhood associations eventually became crucial entities for the transformation of local governance toward more horizontal and participatory, and they became recognized partners for local authorities. One NA representative described it as follows:

The city administration needs us; they need some feedback when they make plans, and they need someone to talk with. We are the intermediaries between citizens' voice and the city council. If some neighborhoods do not have associations, the city needs to spend their own resources to get some output. We know priorities, we can directly provide like 10 points, which are important, and other things that can wait... We have a broader helicopter view that the normal day-to-day inhabitant does not have time for. We realize we are an important media to provide direct access for information about what is happening in the city." (INT_02).

The new cultural strategy 2017-2030 builds on the concept of a neighborhood and sets the strategic priorities for the development of cultural services there. To achieve the development, the municipality aims to develop creative quarters and territories in Riga, which are supposed to improve the quality of neighborhood environments, strengthen local identity, and promote a sense of community (Riga City Council [Rīgas dome], 2017). In 2016, the Riga 
City Council established a funding program for creative quarters and territories. Legal entities, nongovernmental organizations, and private commercial companies can apply for financial support to organize cultural events that satisfy three criteria: create additional environmental aesthetics, involve public participation, and target one of the 58 neighborhoods. The financial support implies co-financing of the projects with no more than $50 \%$ of the estimated costs and cannot exceed 10,000 euro (Riga City Council, 2016).

One of the representatives of the Riga City Council explained that the idea of creative quarters "was created to provide administrative help to the neighborhood NGOs, because otherwise it is impossible for them to cover salaries and rents." (INT_09). This again illustrates how important NAs are for the municipality as the main producers of cultural services in city neighborhoods and crucial actors for community development. In the most recent cultural strategy for 2017-2030, a special role is therefore given to NGOs: "NGOs played an important role in the ECoC 2014 program and had a long-term impact on the development of communities, neighborhoods and creative districts, as well as cultural policies at the state and municipal level" (Riga City Council [Rīgas dome], 2017, p. 11).

\subsubsection{Improving Inclusiveness of Cultural Strategy}

During the ECoC, an innovative communication strategy for cultural programs was developed. The city had quite a strong infrastructure for highbrow cultural consumption, such as historical museums, art galleries, theater, and opera. However, these activities engaged only a small share of the population (INT_04). Moreover, cultural services were not spatially accessible to a large number of residents due to their concentration in the center and absence in residential areas (INT_14). Research on cultural consumption in Riga before the ECoC showed that only 15\% of the population were active cultural consumers (Riga City Council [Rìgas dome], 2017). The ECoC Foundation decided that instead of targeting those $15 \%$, the program should target the $85 \%$ who did not (actively) participate in cultural life (INT_14). Widening participation has become one of the key objectives throughout the event. This was achieved through offering diverse types of cultural activities, making most of the events ticket-free, and improving the communication strategy. For example, the pamphlets used popular language rather than art jargon to appeal to a broader audience; they also incorporated humor and illustrations to appeal to people's emotions and feelings. This approach to communication even caused certain dissatisfaction among the professional artists whose artworks were reformulated from professional art terminology into a simplified form (ibid.).

To conclude, this section illustrated how the emergent cultural strategy appeared to react to the conditions of economic crisis and urban shrinkage. The emergent strategy was initiated by cultural professionals from the ECoC Foundation and codeveloped with local residents, neighborhood associations, and public authorities. The involvement of local residents and neighborhood associations resulted in a place-sensitive, affordable, and inclusive approach that caters to local needs and utilizes locally available resources. The collaboration between the diverse actors resulted in the development of creative and experimental strategic visions and civic empowerment. The analysis revealed how the emergent strategy delivered successful results that were recognized by public authorities and triggered changes in the deliberate cultural strategy for 2017-2030.

\section{Discussion and Conclusion}

In the last decade, research on cultural regeneration in declining areas has been shifting away from pro-growth models in pursuit of sustainable strategies. Recent studies have explored small-budget cultural strategies, community-led activities, locally sensitive cultural programs, and other schemes that could be more relevant for the specific conditions of shrinking cities 
(Della Spina et al., 2019; Grams \& Warr, 2003; Heath et al., 2017; Joo \& Hoon Park, 2017; Koizumi, 2015). This paper aimed to follow this debate and contribute to the literature that seeks more sustainable cultural strategies for shrinking cities (more affordable, socially oriented, and sensitive to local resources and needs).

First, we analyzed the impact of urban shrinkage on the cultural field. Due to the lack of a sufficient empirical base and limited data to establish the correlation, we developed several theory-driven assumptions. Then, based on the case study of Riga - a post-socialist capital city that lost over one third of its population - we investigated a) how the consequences of urban shrinkage were addressed in the emergent and deliberate cultural strategies and b) what planning and governance instruments were used for this purpose. Our results revealed the following:

(1) From the theory, we found that urban shrinkage leads to a decline in the variety of cultural consumption, particularly in the highbrow arts. Thus, changes in cultural offers are required. In Riga, as a response to a low cultural consumption (only $15 \%$ of the population in 2008 ), the ECoC Foundation developed measures to improve cultural accessibility by not only widening local, popular, and amateur cultural offers but also adapting their cultural communication strategy to be more inviting for diverse social groups, including the disadvantaged and marginalized.

(2) Based on the literature, we conclude that urban shrinkage leads to cultural budget cuts and thus to declining numbers and quality of cultural services. In Riga, state and municipal cultural funding experienced significant cuts (by $42 \%$ and $49 \%$ respectively). The lack of investments hindered the construction of cultural "hardware" (infrastructure) and helped to bring the focus to cultural "software" (investment and support for cultural institutions and their activities). Sacco and Blessi (2009) argue that without supporting "software," investments in cultural infrastructure might result in a "dysfunctional 'cosmetic' character that is likely to exacerbate the critical aspects of urban transformation rather than tempering them" (p. 1115). However, the authors also argue that a careful balance between the physical and intangible components of cultural initiatives is required for efficient cultural development. The Riga case study demonstrates that a lack of physical public spaces in neighborhoods hinders the capacity of neighborhood associations and community participation. Therefore, a sufficient level of cultural physical infrastructure is needed as a base for cultural "software."

(3) Urban shrinkage results in an uneven (often centralized) distribution of cultural infrastructure services that reinforces socio-spatial segregation. The city of Riga has faced this challenge: the majority of cultural institutions are located in the city center, while $65 \%$ of residential neighborhoods do not have any cultural institutions in their vicinity. The municipality selected cultural decentralization as one of the key priorities for cultural strategy. The spatial concept that divided the city into 58 neighborhoods was a tool that stimulated the decentralization process. Another tool involved the allocation of small funding schemes and the attraction of experts to improve the capacities of civic organizations.

(4) The theory suggests that while shrinking cities often emphasize the use of culture as a marketing and economic tool, they do not use it sufficiently to address negative social and mental consequences in shrinking cities. Riga's first cultural strategy placed strong emphasis on the development of a creative industries to generate financial returns, and it prioritized investors' and international tourists' interests. The successful emergent strategy during the ECoC allowed the municipality to realized that cultural policy can be effective in combination with other policies, such as social cohesion, civic participation, and community integration. This led to an expansion of the role of culture in the deliberate strategy by switching from an economized to a socially driven approach. 
The second and third research questions aimed to explore what an alternative to progrowth cultural strategy is, and how it is developed (i.e., with what planning or governance instruments). The alternative cultural strategy analyzed in this paper is based on five elements supported by several implementation instruments, summarized in Table 2.

Table 2

Elements of an Alternative Cultural Strategy and Instruments for Their Implementation.

\begin{tabular}{|c|c|c|}
\hline № & $\begin{array}{l}\text { Elements of an alternative cultural strategy in } \\
\text { shrinking cities }\end{array}$ & Implementation instruments \\
\hline 1 & $\begin{array}{l}\text { Shifting the focus from cultural "hardware" to cultural } \\
\text { "software" - from large investments in cultural } \\
\text { infrastructure to smaller investments in cultural } \\
\text { institutions, their capacities, and social and identity } \\
\text { assets }\end{array}$ & $\begin{array}{l}\text { 1. Allocation of funding schemes (financial } \\
\text { competitions) for individual projects of } \\
\text { cultural institutions. }\end{array}$ \\
\hline 2 & $\begin{array}{l}\text { Ensuring locally sensitive approach to cultural } \\
\text { development }\end{array}$ & \multirow[b]{2}{*}{$\begin{array}{l}\text { 1. Promoting cultural development in } \\
\text { smaller urban areas, such as city } \\
\text { neighborhoods (based around cultural } \\
\text { institutions, heritage, historical identity, } \\
\text { etc.). } \\
\text { 2. Conducting research to identify areas } \\
\text { with limited access to cultural amenities. } \\
\text { 3. Providing funding schemes for civic } \\
\text { actors to realize their ideas in the } \\
\text { neighborhoods. } \\
\text { 4. Consulting with experts on improving } \\
\text { the feasibility of bottom-up projects. } \\
\text { 5. Engaging volunteers in the organization } \\
\text { and implementation of projects. }\end{array}$} \\
\hline 3 & Improving cultural decentralization & \\
\hline 4 & Strengthening civic empowerment and participation & $\begin{array}{l}\text { 1. Promoting the idea of identity, a sense of } \\
\text { belonging, and community building in } \\
\text { smaller spatial areas. } \\
\text { 2. Initiating project calls for cultural and } \\
\text { civic activities in those areas. } \\
\text { 3. Providing sufficient resources for the } \\
\text { realization of civic projects (e.g., } \\
\text { financial resources, knowledge and } \\
\text { skills, physical working space). }\end{array}$ \\
\hline 5 & $\begin{array}{l}\text { Improving cultural inclusiveness for social groups } \\
\text { prevailing in shrinking areas (e.g., the elderly, the poor, } \\
\text { and the socially disadvantaged) }\end{array}$ & $\begin{array}{l}\text { 1. Conducting research on cultural } \\
\text { participation and satisfaction with } \\
\text { cultural services. } \\
\text { 2. Expanding the range of ticket-free } \\
\text { cultural activities. } \\
\text { 3. Expanding the range of popular and } \\
\text { amateur types of cultural offers and } \\
\text { promoting local instead of international } \\
\text { culture. } \\
\text { 4. Adopting an inclusive communication } \\
\text { strategy (strengthening visual and written } \\
\text { languages). } \\
\text { 5. Developing cultural services and } \\
\text { amenities in residential areas in close } \\
\text { physical vicinity to socially excluded } \\
\text { groups (e.g., multifunctional cultural } \\
\text { centers in the neighborhoods. }\end{array}$ \\
\hline
\end{tabular}


In the debate on shrinking cities, many authors advocate for a shift from a growthoriented approach toward "shrinking smart" - moving the goal from reversing population decline to guaranteeing "quality of life that ensures the maintenance of the municipality as a pleasant place to live" (Panagopoulos \& Barreira, 2012). Our study contributes to this argument. Even though the urban development strategy in Riga is still based on predictions of demographic growth by facilitating return migration, resident retention, and support for families, the cultural strategy has been transitioning toward the "smart shrinkage" approach. Addressing the effects of urban shrinkage and economic crisis in Riga has resulted in a shift toward a more inclusive, socially driven, and locally sensitive cultural strategy.

The dominance of pro-growth planning strategies in shrinking cities reflects their stigmatization and local authorities' refusal to accept a shrinking pathway (Leo \& Anderson, 2006). However, some scholars have argued that urban shrinkage can be the opportunity for cities to re-envision themselves as more livable and sustainable places that deliver a high quality of life for certain groups of the population (Blanco et al., 2009; Haase et al., 2012). This argument has been illustrated through the analysis of the Riga case study: even under conditions of severe urban shrinkage and economic crisis, cities can be the forerunners of innovative strategies for urban development. The severe local conditions in shrinking cities can be used as an opportunity to experiment with resource management, service provision, and civic engagement. This research illustrates that the emergent actions of civic actors can result in innovative and sustainable strategies. The emergent strategy of the ECoC delivered successful results, which were recognized by public authorities and stimulated changes in the deliberate cultural strategy. This became possible due to a) civic actors' sufficient organizational capacities to collaborate, experiment, and open the door to strategic learning; $b$ ) the resources allocated through the $\mathrm{ECoC}$ fund, and c) public authorities' ability to recognize the novel emergent patterns and anchor them in the deliberate strategy. Therefore, this study supports the idea that urban shrinkage offers planners and policymakers an opportunity to reimagine cities and the traditional principles on which planning practice has been based. Moreover, our research highlights the role of civic society's participation in coproducing public services and governance strategies. Opening the planning process to residents, NGOs, and cultural institutions provides local authorities with local knowledge and access to local resources and creativity, which stimulate innovative and place-sensitive solutions.

We adopted a longitudinal single-case-study research design to extensively explore an "actually existing" shrinking city and to investigate the alternative cultural strategy elements and tools in this specific context. However, this type of design has limitations that must be acknowledged. With a single-case study, the generalizability of findings is constrained: the case of Riga provides one particular example of an alternative cultural strategy in a postsocialist capital city; the findings reached in this study might thus not replicate in other contexts of shrinking cities. Further research on diverse cases of shrinking cities is hence needed to gain a more comprehensive understanding of the alternative cultural strategies, their elements, and tools for their implementations. Furthermore, additional empirical research is required to determine the impact of urban shrinkage on the cultural field, particularly in shrinking cities where there is access to longitudinal data on the accessibility of cultural services and infrastructure.

\section{Acknowledgment}

This research received funding from the European Union's Horizon 2020 research and innovation program under the Marie Skłodowska-Curie grant agreement No 813803. 


\section{References}

Audirac, I. (2018). Shrinking cities: An unfit term for American urban policy? Cities, 75(January), 12-19. https://doi.org/10.1016/j.cities.2017.05.001

Beauregard, R. A. (2009). Urban population loss in historical perspective: United States, 18202000. Environment and Planning A, 41(3), 514-528. https://doi.org/10.1068/a40139a

Berglund, L. (2020). Critiques of the shrinking cities literature from an urban political economy framework. Journal of Planning Literature, 35(4), 423-439. https://doi.org/10.1177/0885412220928507

Bianchini, F., \& Parkinson, M. (1993). Cultural policy and urban regeneration. The West European experience. Manchester University Press.

Bierbaum, A. H. (2020). Managing shrinkage by "right-sizing" schools: The case of school closures in Philadelphia. Journal of Urban Affairs, 42(3), 450-473. https://doi.org/10.1080/07352166.2020.1712150

Binns, L. (2005). Capitalising on culture: an evaluation of culture-led urban regeneration policy. Futures Academy, Technological University Dublin, 118-124. Retrieved from http://arrow.dit.ie/futuresacart/5/

Blanco, H., Alberti, M., Olshansky, R., Chang, S., Wheeler, S. M., Randolph, J., London, J. B., Hollander, J. B., Pallagst, K. M., Schwarz, T., Popper, F. J., Parnell, S., Pieterse, E., \& Watson, V. (2009). Shaken, shrinking, hot, impoverished and informal: Emerging research agendas in planning. Progress in Planning, 72(4), 195-250. https://doi.org/10.1016/j.progress.2009.09.001

Bourdieu, P. (1984). Distinction: A social critique of the judgement of taste. Harvard University Press.

Cortese, C., Haase, A., Grossmann, K., \& Ticha, I. (2014). Governing Social cohesion in shrinking cities: The cases of Ostrava, Genoa and Leipzig. European Planning Studies, 22(10), 2050-2066. https://doi.org/10.1080/09654313.2013.817540

De Franz, M. (2013). Regeneration and discursive politics. In M. E. Leary \& J. McCarthy (Eds.), The Routledge Companion to Urban Regeneration. Taylor \& Francis.

Della Spina, L., Giorno, C., \& Galati Casmiro, R. (2019). Bottom-up processes for culture-led urban regeneration scenarios. In S. Misra, O. Gervasi, B. Murgante, E. Stankova, V. Korkhov, C. Torre, A. M. A. C. Rocha, D. Taniar, B. O. Apduhan, \& E. Tarantino (Eds.), Computational Science and Its Applications - ICCSA 2019. Springer, Cham. https://doi.org/https://doi.org/10.1007/978-3-030-24305-0_8

European Commission. (2011). Demography report 2010: Older, more numerous and diverse Europeans. https://doi.org/10.2767/79004

European Commission. (2015). Ex-post evaluation of the European Capitals of Culture. Final report. Publications Office of the European Union. https://doi.org/10.2766/88424

European Commission. (2020). Report on the impact of demographic change. Retrieved from https://ec.europa.eu/info/sites/info/files/demography_report_2020_n.pdf

Fol, S. (2012). Urban Shrinkage and socio-spatial disparities: Are the remedies worse than the disease? Built Environment, 38(2), 259-275. http://www.jstor.org/stable/23799124

Galuszka, J. (2017). Examining patterns of policy change in a post-socialist city: the evolution of inner-city regeneration approaches in Łódź, Poland, after 1989. Town Planning Review, 88(6), 639-664. https://doi.org/10.3828/tpr.2017.39

Gerring, J. (2007). Case study research: Principles and practices (2nd ed.). Cambridge University Press. https://doi.org/DOI: 10.1017/CBO9780511803123

Grams, D., \& Warr, M. (2003). Leveraging assets: How small budget arts activities benefit neighborhoods. The John D. and Catherine T. MacArthur Foundation. Retrieved from https://www.issuelab.org/resources/14847/14847.pdf

Gribat, N. (2017). Overcoming decline through graffiti? The case of the Open Space Gallery 
in Halle ( Saale ). Metropolitics, 1-8. Retrieved from https://www.metropolitiques.eu/Overcoming-Decline-Through.html

Grodach, C. (2010). Beyond bilbao: Rethinking flagship cultural development and planning in three California cities. Journal of Planning Education and Research, 29(3), 353-366. https://doi.org/10.1177/0739456X09354452

Gugane, Z. (2020). Promotion of neighbourhood communities - the key to cooperation between the municipality and residents. URBACT. Retrieved from https://urbact.eu/promotionneighbourhood-communities--key-cooperation-between-municipality-and-residents

Haase, A., Hospers, G., Pekelsma, S., Rink, D., \& Grisel, M. (2012). Shrinking areas. Frontrunners in innovative citizen participation. European Urban Knowledge Network.

Hackworth, J. (2015). Rightsizing as spatial austerity in the American Rust Belt. Environment and Planning A: Economy and Space, 4(47), 766-782. https://doi.org/10.1068/a140327p

Hartt, M., \& Warkentin, J. (2017). The development and revitalisation of shrinking cities : a twin city comparison. Town Planning Review, 88(1), 29-41. https://doi.org/https://doi.org/10.3828/tpr.2017.4

Hazans, M. (2013). Emigration from Latvia: Recent trends and economic impact. In Coping with Emigration in Baltic and East European Countries (OECD). OECD Publishing. https://doi.org/10.1787/9789264204928-7-en

Hazans, M. (2019). Emigration from Latvia: A brief history and driving forces in the twentyfirst century. In R. Kaša \& I. Mierina (Eds.), The Emigrant Communities of Latvia (IMISCOE Re, pp. 35-68). https://doi.org/10.1007/978-3-030-12092-4_3

Heath, S. C., Rabinovich, A., \& Barreto, M. (2017). Putting identity into the community: Exploring the social dynamics of urban regeneration. European Journal of Social Psychology, 47(7), 855-866. https://doi.org/10.1002/ejsp.2296

Henley, D. (2016). The arts dividend: Why investment in culture pays. Elliott and Thompson Limited London, UK.

Hollander, J. B., \& Németh, J. (2011). The bounds of smart decline: A foundational theory for planning shrinking cities. Housing Policy Debate, 21(3), 349-367. https://doi.org/10.1080/10511482.2011.585164

Hospers, G. J. (2013). Coping with shrinkage in Europe's cities and towns. Urban Design International, 18(1), 78-89. https://doi.org/10.1057/udi.2012.29

Hospers, G. J. (2014). Policy responses to urban shrinkage: From growth thinking to civic engagement. European Planning Studies, 22(7), 1507-1523. https://doi.org/10.1080/09654313.2013.793655

Joo, Y. M., \& Hoon Park, S. (2017). Overcoming urban growth coalition: The case of cultureled urban revitalization in Busan, South Korea. Urban Affairs Review, 53(5), 843-867. https://doi.org/10.1177/1078087416638449

Katz-Gerro, T. (2002). Highbrow cultural consumption and class distinction in Italy, Israel, West Germany, Sweden, and the United States. Social Forces, 81(1), 207-229. https://doi.org/10.1353/sof.2002.0050

Koizumi, M. (2015). Creativity in a shrinking society: A case study of the Water and Land Niigata Art Festival. Cities, 56, 141-147. https://doi.org/10.1016/j.cities.2015.10.002

Krasnopjorovs, O. (2011). Cik cilvēku Latviju pameta, un cik vēl pametīs? [How many people have left Lativa and how many people will leave?]. Retrieved from https://www.makroekonomika.lv/cik-cilveku-latviju-pameta-un-cik-vel-pametis

Leo, C., \& Anderson, K. (2006). Being realistic about urban growth. Journal of Urban Affairs, 28(2), 169-189. https://doi.org/10.1111/j.0735-2166.2006.00266.x

Lin, C. Y., \& Hsing, W. C. (2009). Culture-led urban regeneration and community mobilisation: The case of the Taipei Bao-an Temple area, Taiwan. Urban Studies, 46(7), 1317-1342. https://doi.org/10.1177/0042098009104568 
Lyman, R. L. (2007). What is the "process" in cultural process and in processual archaeology? Anthropological Theory, 7(2), 217-250. https://doi.org/10.1177/1463499607077299

Lysgård, H. K. (2012). Creativity, culture and urban strategies: A fallacy in cultural urban strategies. European Planning Studies, 20(8), 1281-1300. https://doi.org/10.1080/09654313.2012.680581

Martinez-Fernandez, C., Weyman, T., Fol, S., Audirac, I., Cunningham-Sabot, E., Wiechmann, T., \& Yahagi, H. (2016). Shrinking cities in Australia, Japan, Europe and the USA: From a global process to local policy responses. Progress in Planning, 105, 1-48. https://doi.org/10.1016/j.progress.2014.10.001

Mintzberg, H., Ahlstrand, B., \& Lampel, J. (1998). Strategy safari: a guided tour through the wilds of strategic management. New York: Free Press.

Miot, Y. (2015). Residential attractiveness as a public policy goal for declining industrial cities: Housing renewal strategies in Mulhouse, Roubaix and Saint-Etienne (France). European Planning Studies, 23(1), 104-125. https://doi.org/10.1080/09654313.2013.820098

Moulaert, F., Demuynck, H., \& Nussbaumer, J. (2004). Urban renaissance: from physical beautification to social empowerment. City, 8(2), 229-235. https://doi.org/10.1080/1360481042000242175

Nedučin, D., Krklješ, M., \& Gajić, Z. (2019). Post-socialist context of culture-led urban regeneration - Case study of a street in Novi Sad, Serbia. Cities, 85, 72-82. https://doi.org/10.1016/J.CITIES.2018.11.024

Panagopoulos, T., \& Barreira, A. P. (2012). Shrinkage perceptions and smart growth strategies for the municipalities of Portugal. Built Environment (1978-), 38(2), 276-292. https://doi.org/10.2148/benv.38.2.276

Pastak, I., \& Kährik, A. (2017). The impacts of culture-led flagship projects on local communities in the context of post-socialist Tallinn. Czech Sociological Review, 52(6), 963-990. https://doi.org/10.13060/00380288.2016.52.6.292

Peterson, R. A. (1992). Understanding audience segmentation: from elite and mass to omnivore and univore. Poetics, 21(4), 234-258. https://doi.org/https://doi.org/10.1016/0304$422 \mathrm{X}(92) 90008-\mathrm{Q}$

Prior, L. (2014). Content analysis. In P. Leavy (Ed.), The Oxford handbook of qualitative research (pp. 359-379). Oxford University Press. https://doi.org/10.1093/oxfordhb/9780199811755.013.008

Riga City Council. (2016). Financial competitions [Finansēšanas konkursi]. Retrieved from https://kultura.riga.lv/lv/kultura/finansesanas-konkursi?page $=2$

Riga City Council. (2021). Cultural institutions [Kultūras iestādes]. Retrieved from https://apkaimes.lv/statistika/kulturas-iestades/

Riga City Council [Rīgas dome]. (2005a). Riga development programme for 2006-2012. [Rīgas attīstības programma 2006.-2012]. Retrieved from https://www.rdpad.lv/wpcontent/uploads/2014/12/Rigas_attistibas_programma_2006.-2012.g.pdf

Riga City Council [Rīgas dome]. (2005b). Riga long-term development strategy until 2025 [Rìgas ilgterminga attīstības stratēgija lìdz 2025. gadam]. Retrieved from https://www.rdpad.lv/wpcontent/uploads/2014/12/Rigas_ilgtermina_attistibas_strategija_2025.g.pdf

Riga City Council [Rīgas dome]. (2008). R̄̄gas pilsētas kultūras stratēégija 2008.-2025.gadam [Cultural strategy of the city of Riga for 2008-2025]. Retrieved from https://sus.lv/registrs/pilsetas-parvaldiba/rigas-pilsetas-pasvaldibas-kulturas-strategija2008-2025gada

Riga City Council [Rīgas dome]. (2014a). Appendix to Riga development program for 20142020. Description of current situation [Pašreizējās situācijas raksturojums].

Riga City Council [Rīgas dome]. (2014b). Riga sustainable development strategy until 2030 
[Rīgas ilgtspējīgas attīstības stratēgija lìdz 2030. gadam]. Retrieved from https://www.rdpad.lv/wp-content/uploads/2014/11/STRATEGIJA_WEB.pdf

Riga City Council [Rīgas dome]. (2017). Rìgas pilsētas pašvaldības kultūras stratēgija 2017.2030.gadam [Municipal cultural strategy of the city of Riga for 2017-2030]. Retrieved from https://iksd.riga.lv/media/RD_IKSD/normativie_akti/kulturas_strategija_Nr_5430\%20(2 ).doc

Rink, D., Haase, A., Bernt, M., \& Grossmann, K. (2010). Addressing urban shrinkage across Europe - challenges and prospects Shrink Smart research brief No. 1, November 2010 (Issue 1). Retrieved from https://shrinksmart.ufz.de/data/D9 Research Brief 214223.pdf

Ročak, M., Hospers, G. J., \& Reverda, N. (2016a). Civic action and urban shrinkage: Exploring the link. Journal of Urban Regeneration and Renewal, 9(4), 406-418. Retrieved from https://www.ingentaconnect.com/content/hsp/jurr/2016/00000009/00000004/art00008

Ročak, M., Hospers, G. J., \& Reverda, N. (2016b). Searching for social sustainability: The case of the shrinking city of Heerlen, the Netherlands. Sustainability, 8(4), 382. https://doi.org/10.3390/su8040382

Rousseau, M. (2009). Re-imaging the city centre for the middle classes: Regeneration, gentrification and symbolic policies in "loser cities." International Journal of Urban and Regional Research, 33(3), 770-788. https://doi.org/10.1111/j.1468-2427.2009.00889.x

Rumpel, P., Slach, O., \& Koutskỳ, J. (2013). Shrinking cities and governance of economic regeneration: The case of Ostrava. Ekonomika a Management, 16(2), 113-128.

Sacco, P., \& Blessi, G. T. (2009). The social viability of culture-led urban transformation processes: Evidence from the Bicocca District, Milan. Urban Studies, 46(5-6), 11151135. https://doi.org/10.1177/0042098009103857

Sayer, A. (2001). For a critical cultural political economy. Antipode, 33(4), 687-708. https://doi.org/10.1111/1467-8330.00206

Schenkel, W. (2015). Regeneration strategies in shrinking urban neighbourhoods - dimensions of interventions in theory and practice. European Planning Studies, 23(1), 69-86. https://doi.org/10.1080/09654313.2013.820089

Schetke, S., \& Haase, D. (2008). Multi-criteria assessment of socio-environmental aspects in shrinking cities. Experiences from eastern Germany. Environmental Impact Assessment Review, 28, 483-503. https://doi.org/10.1016/j.eiar.2007.09.004

Schilling, J., \& Logan, J. (2008). Greening the rust belt: A green infrastructure model for right sizing America's shrinking cities. Journal of the American Planning Association, 74(4), 451-466. https://doi.org/10.1080/01944360802354956

Schlappa, H. (2017). Co-producing the cities of tomorrow: Fostering collaborative action to tackle decline in Europe's shrinking cities. European Urban and Regional Studies, 24(2), 162-174. https://doi.org/10.1177/0969776415621962

Seo, J.-K. (2002). Re-urbanisation in regenerated areas of Manchester and Glasgow. Cities, 19(2), 113-121. https://doi.org/10.1016/s0264-2751(02)00006-9

Slach, O., Bosák, V., Krtička, L., Nováček, A., \& Rumpel, P. (2019). Urban shrinkage and sustainability: Assessing the nexus between population density, urban structures and urban sustainability. Sustainability, 11(15), 4142. https://doi.org/10.3390/su11154142

Stake, R. (2000). The case study method in social inquiry. In N. K. Denzin \& Y. S. Lincoln (Eds.), Handbook of qualitative research. Sage Publications.

Wiechmann, T. (2007). Induced versus autonomous behaviour in regional development - a process model for regional strategy formation. XXI AESOP - Association of European Schools of Planning Conference, Planning of the Risk Society. Retrieved from http://www2.ioer.de/recherche/pdf/2007_wiechmann_aesop.pdf

Wiechmann, T., \& Bontje, M. (2015). Responding to tough times: Policy and planning 
strategies in shrinking cities. European Planning Studies, 23(1), 1-11. https://doi.org/10.1080/09654313.2013.820077

Wiechmann, T., \& Wolff, M. (2013). Urban shrinkage in a spatial perspective operationalization of shrinking cities in Europe 1990-2010. AESOP-ACSP Joint Congress.

Williams, R. (1985). Keywords: a vocabulary of culture and society. New York: Oxford University Press.

Winkler, R., Oikarinen, L., Simpson, H., Michaelson, M., \& Gonzalez, M. S. (2016). Boom, bust and beyond: Arts and sustainability in Calumet, Michigan. Sustainability (Switzerland), 8(3). https://doi.org/10.3390/su8030284

Zukin, S. (1995). The cultures of cities. Cambridge, MA: Blackwell.

\section{Appendix - List of interviews}

\begin{tabular}{|l|l|l|l|}
\hline No. & Reference & Date & Type of organization \\
\hline 1 & INT_01 & 28.10 .2019 & Representative of Riga City Council \\
\hline 2 & INT_02 & 28.10 .2019 & Representative of a local neighbourhood association, also a resident \\
\hline 3 & INT_03 & 29.10 .2019 & Representative of the Latvian National Tourism Board \\
\hline 4 & INT_04 & 31.10 .2019 & $\begin{array}{l}\text { Representative of a local cultural NGO, also representative of European } \\
\text { Capital of Culture Board }\end{array}$ \\
\hline 5 & INT_05 & 01.11 .2019 & Representative of a local NGO \\
\hline 6 & INT_06 & 28.08 .2020 & Representative of a local cultural NGO \\
\hline 7 & INT_07 & 05.09 .2020 & Independent artist representative, who collaborates with the local NGO \\
\hline 8 & INT_08 & 07.09 .2020 & Representative of Riga City Council \\
\hline 9 & INT_09 & 07.09 .2020 & Representative of Riga City Council \\
\hline 10 & INT_10 & 07.09 .2020 & Representative of Riga City Council \\
\hline 11 & INT_11 & 07.09 .2020 & Representative of a local cultural NGO \\
\hline 12 & INT_12 & 09.09 .2020 & Cultural manager representative \\
\hline 13 & INT_13 & 14.09 .2020 & Private investor representative \\
\hline 14 & INT_14 & 15.09 .2020 & $\begin{array}{l}\text { Representative of Riga City Council (former employee), also representative } \\
\text { of European Capital of Culture Board }\end{array}$ \\
\hline 15 & INT_15 & 18.09 .2020 & Representative of a local urban design bureau \\
\hline 16 & INT_16 & 18.09 .2020 & Representative of a local cultural NGO \\
\hline 17 & INT_17 & 18.09 .2020 & $\begin{array}{l}\text { Representative of a local cultural NGO, also representative of European } \\
\text { Capital of Culture Board }\end{array}$ \\
\hline 18 & INT_18 & 21.09 .2020 & Representative of an international cultural institute, located in Riga \\
\hline 19 & INT_19 & 22.09 .2020 & Representative of a local neighbourhood association, also a local activist \\
\hline 20 & INT_20 & 12.10 .2020 & Representative of a local NGO \\
\hline 21 & INT_21 & 05.05 .2021 & Representative of a local neighbourhood association, also a resident \\
\hline
\end{tabular}

